Spirits out of place : relational landscapes and environmental change in East Kalimantan, Indonesia

\title{
Herrmans, Isabell
}

2020-12

Herrmans , I 2020 , ' Spirits out of place : relational landscapes and environmental change in East Kalimantan, Indonesia ' , Journal of the Royal Anthropological Institute , vol. 26 , no. 4 , pp. 766-785 . https://doi.org/10.1111/1467-9655.13413

http://hdl.handle.net/10138/335622

https://doi.org/10.1111/1467-9655.13413

acceptedVersion

Downloaded from Helda, University of Helsinki institutional repository.

This is an electronic reprint of the original article.

This reprint may differ from the original in pagination and typographic detail.

Please cite the original version. 


\title{
Spirits out of place: relational landscapes and environmental change in East Kalimantan, Indonesia
}

IS A B ELL HERRMANS University of Helsinki

\begin{abstract}
This article examines interaction with spirits among the Luangan, a group of shifting cultivators in Indonesian Borneo. Through examples of different forms of Luangan spirit interaction, it interrogates the relationship between the spirit world and the natural environment, with special reference to what happens when the latter undergoes dramatic change. Inspired by Eduardo Kohn's understanding of how the spirit world is semiotically embedded within the rainforest environment, I explore how relations with nonhumans reflect historical and ongoing experiences of life and sociality in the forest and human domain, while superimposing a virtual relational landscape upon the natural landscape. It is proposed that spirit communication offers a means of refiguring human lives and alleviating debilitation, and that recurrent rituals enable Luangans to virtually maintain relations with unseen beings of the local environment, even where it has been thoroughly transformed through oil palm cultivation.
\end{abstract}

Feeling a sudden gust of cold air and the hair on the back of his neck standing up on end, Tanto sensed the presence of a wok, a ghost-like spirit, late one night in 2015 as he was driving his motorbike home from a visit to a neighbouring village. He then saw the spirit, a woman with long black hair hovering in the air on the side of the road, dressed in a white robe of the type that corpses are wrapped in. Terrified, he stepped on the gas, but it felt like the motorbike was held back, only slowly crawling up the hill. When he finally made it to a cluster of small houses near a swidden field in the vicinity, he noticed that the drivetrain of the bike was broken. Three days later, as Tanto returned to the district capital where he went to junior high school, he learned that a truck with Banjar Malay traders, out to collect bamboo, had turned over at that very same spot, killing one of them.

Like the forest paths that provided the main routes of movement through the local landscape of the Luangans when I first got to know it in the 1990s, the subsequently constructed dirt and asphalt roads now linking most villages in this upriver area of East Kalimantan, Indonesian Borneo, have become scenes of encounters between humans and nonhumans of different kinds. As Tanto's story reveals, these sometimes uncanny encounters may not only involve human and spirit agents, but increasingly they also 
feature motor vehicles, such as trucks and motorbikes, and sometimes other locally novel objects, like mobile phones, making up precarious assemblages of distributed agency. For Luangans, as for visitors to the area, the effects of such entanglements can be serious. This is why it might be wise to treat 'signs', such as the wok standing by the road, or the broken motorbike, as meaningful communication.

Inspired by Eduardo Kohn's adaptation of Charles Peirce's theory of signification, and his insights that living beings are constitutively semiotic and 'selfhood' is the product of the intrinsically social process of semiosis, this article considers how humans relate to other kinds of beings in what Kohn calls 'ecologies of selves' (2013). A 'self, in Kohn's understanding, 'is the locus ... of a living dynamic by which signs come to represent the world around them to a "someone" who emerges as such as a result of this process' (2013: 16). This has two fundamental implications for this article. First, living beings - through their representations of self and other - are constitutively co-created in an eminently social process; where people live in the presence of nonhuman others, these are implicated in this process as interlocutors. Second, semiosis as a process is situated in and reflective of the world in which beings make their living; representations of others, including spirits, emerge from practices and experiences in that world.

Like the Runa of Ecuador studied by Kohn, Luangans perceive that the natural environment is home to a multitude of nonhuman beings, among them an abundance of different spirits, who are attributed subjectivity and communicate things to them. This article probes some of the principal forms of Luangan interaction with spirits - omens, dreams, unforeseen in situ encounters, and rituals - with a view to understanding the multifaceted relationship between such experiences and imaginaries and the material world in which they are embedded. The aim is to analyse how these forms of interaction express and affect experiences in the lived-in relational landscape, with special attention to what happens when the environment - in this case the tropical rainforest - undergoes sudden radical change. It is proposed that the maintenance of diverse relations with spirits reproduces a variegated relational landscape overlying the physical terrain, which facilitates a future-orientated negotiation of life conditions in a virtual realm of possibilities. The article presents a distinct argument about the nature of the rationale of spirit interaction, which goes beyond new animism theory's understanding of the personification of nonhuman entities as the derivative of an ontology predicated on a continuous subject-object relationship (e.g. Descola 2006). Rather than seeking the sources of more-than-human subjectification and conceptions of the domain of 'supernature' in ontologically foundational schemes of thought or perception (e.g. Viveiros de Castro 1998), it suggests that more pragmatic concerns of promoting concrete ongoing liveability provide the principal incentives for maintaining relations with spirits and significantly shape these relations.

In 2009, oil palm companies entered the upriver region where the shifting cultivator Luangans live, rapidly turning vast areas of secondary and primary tropical rainforest into monocrop oil palm plantations. While enough forest was still left to grow swidden rice in the area when I last visited it in 2017 , it is - as many of the inhabitants asserted - only a matter of time before all the forest will be converted into plantations. Along with this pervasive transformation of the local environment, a range of social and economic changes also occurred, following decreasing opportunities for traditional subsistence through shifting cultivation and forest use, new opportunities and demands for obtaining and using money through land sales and labour, and increasing access to markets and consumer goods. This article considers how these changes have affected 
the relational ecology of human and nonhuman agents in the environment, and the importance of the forested environment for its reproduction.

It should be noted that the present article offers more of a commentary on a problem than a resolution. This is not only because we are dealing with an ongoing process that has just recently started, making its implications hard to foretell. It is also because, if fieldwork among the Luangans has ever taught me anything, it is that there is no predictability or certainty in dealing with spirits, and that relations with them are subject to continuous negotiation and reinterpretation. While the forms of signification associated with forest life would seem to be undermined by the regime of monoculture that oil palm production and other changes have brought about, the profusion and open-ended quality of rituals that superimpose a relational ecology on the environment appear so far to have deflected a corresponding de-animation or simplification of the Luangans' lifeworld. In fact, it seems that the persistence of ritual relations with nonhumans sustains an expansive, 'sympoietic' (Haraway 2017) mode of relatedness in the transformed environment, which is congruent with historically established 'animistic' ways of dwelling and perceiving. The ritual relations perpetuate a way of relating to other beings in the environment as selves implicated in an open-ended web of co-constitution or 'becoming-with', which encourages a disposition for reading the signs of these beings and inclusively 'making kin' with them. Moreover, on account of their semiotic-communicative virtues, the maintenance of these relations may be specifically motivated by sustaining liveability and hope in the precarious present, even if occasionally in no other way than through evoking an aporia or an unfulfilled desire, by articulating, however indeterminably, the inscrutable or irresolvable.

Contrary to much ethnography on the effects of corporate resource extraction on indigenous peoples in so-called capitalist frontier regions, this article addresses the understudied 'non-secular' (Bubandt 2018; see also de la Cadena 2010) dimensions of their engagement with the changing environment. It explores how forms of signification associated with the diverse forested environment continue to provide imagery and material for representations of the spirit realm, and how the cogency of these representations derives from their openness to the unknown and unexpected. I argue that the maintenance of spirit relations through rituals works to alleviate the sense of unpredictability and alienation that haunts life under capitalist expansion, and furthermore reproduces a long-standing conditional ontology of 'not-knowing', a pragmatic epistemology born out of subjection to the exigencies and contingencies of a complex natural and sociopolitical environment.

\section{The spirit realm and its relation to the environment}

As in many Southeast Asian societies, the natural and domesticated environment is perceived by the Luangans to be 'intersected by a spiritual or invisible realm' (Allerton 2009: 235), which forms a kind of shadow topography of the visible landscape within which it is immanent. The plentiful populace of this realm consists of a variety of 'spirits', including nature spirits, ancestors, ghosts, and 'souls', the invisible and anthropomorphic counterparts of people and certain animals. Causality in the forest and human habitats is personified; conditions and occurrences are often interpreted as the result of the intentional activity of their unseen inhabitants, especially when they involve adverse or inexplicable events. Furthermore, the maintenance of respectful relations with them by means of rituals, and the sacrifices offered thereby, are regarded as essential prerequisites for human well-being. In this respect, Luangan animist 
understandings concord with the typical pattern of Southeast Asian societies, whereby 'ontological intersubjectivity' is centred on human-spirit relations - rather than humananimal relations, as in many Amerindian societies (Århem 2016: 19). Spirits form 'the paradigmatic cosmological others' (Sprenger 2016: 76) through which people's relationships to themselves, to other people, and to the natural environment are mediated (see Sillander 2016: 160). In particular, they are interlocutors in a semiotic process whereby humans interpret and act upon challenging and debilitating life conditions to refigure them and regain agency. More than an important attribute, this property, I suggest, provides their principal relevance to humans and the grounds for a remarkable frequency of Luangan shamanic rituals (belian).

Compared to many other societies identified as animistic (e.g. Willerslev 2007), Luangan spirits are notably numerous and diverse, and therefore they need to be addressed in different ways. There is, in fact, no generic term for 'spirits'. Instead, one finds a huge variety of differently named individual spirits or spirit categories, with their own inclinations, habits, and habitats. Depending on the context, they may roughly be divided into spirit helpers (mulung), malevolent spirits (blis), and guardian spirits (pengiring). While some spirits, such as the wok, are more prone to predation and general depredations than others, all spirits are essentially reversible figures, who may act in different capacities depending on the context. For example, while the refined souls (kelelungan) of ancestors (especially those who were shamans) are the shamans' principal spirit helpers, these souls also regularly return to haunt living people, and may steal their souls. Likewise, naiyu and timang forest spirits are both prominent protective spirits and malevolent spirits, and even the generally dreaded wok can act as spirit helpers in some contexts. Generally during healing rituals, shamans negotiate with numerous different spirits, rather than just a particular spirit thought to have caused a particular illness, both because of the inherent unpredictability of spirits, and so as to include them in relational landscapes. This inclusive relatedness is a distinctive attribute of Luangan animism, which, like the diversity of spirits itself, works to enhance its ability to represent and redress the evasive and adverse qualities of reality.

A perception of the interdependence of actions and conditions between the seen and unseen dimensions establishes a sense of interconnectedness between humans and spirits, and between people and the physical environment, in which the spirits are abundantly and constitutively present. This orientation is congruent with what Nurit Bird-David calls 'responsive relatedness', a disposition for 'expecting response and responding' to entities in the environment as and when they are related with (1999: S77). Such an orientation is based, as Tim Ingold observes, on 'a kind of sensory participation, a coupling of one's attention to the movement of aspects of the world', and is born out of 'a history of intimate engagement' (1999: S82). It is thus noticeably consistent with the 'fleshly' semiosis of the Amazonian rainforest described by Kohn, which fundamentally relies on modes of iconic and indexical interpretation and builds on patterns and regularities in the phenomenal reality, on what he calls 'form' (2013: 20-1). ${ }^{1}$ It is a mode of situated interaction attuned and receptive to conditions in the dwelled-in environment through sensorial impressions.

Simultaneously, however, the Luangan world of unseen spirit agencies is also an 'emergent real' in the same way as the Runa 'realm of the spirit masters', to which in this respect it shows a strong resemblance. Like this realm, it forms a higherorder overlying symbolic pattern, 'a special configuration of concept and kind', which harnesses, yet transcends, historical and ongoing experiences of life and sociality in the 
human-and-natural world from which it emerges (Kohn 2013: 226). As an instance of symbolic reference, it forms a 'virtual' realm, a sphere of 'relaxed spatiotemporal constraints', in which history - in the sense of the effects of past actions on the present - does not wield its ordinary influence (2013: 182). As such, the spirit realm is not only determined by the 'here and now', but also (and crucially) shaped by the 'what if; it is fundamentally informed by intentions and desires, by the future orientations that are constitutive of selves and semiosis (2013:56). Owing to their frequency and privileged status for transmitting knowledge about the unseen dimension, Luangan healing rituals are essential for its reproduction, and they may reproduce the virtual realm and its coordinates in the environment even, I claim, when the environment has been completely transformed.

This article thus considers the continued relevance of Luangan relational landscapes. I perceive that Luangan relations with spirits exemplify an ongoing 'progenerative unfolding' of relationships in Ingold's (2000: 142) understanding, whereby human and nonhuman agents are co-constituted through dwelling, but that this process is thoroughly semiotic in Kohn's broadened sense, enfolding the symbolic and futureorientated modality of semiosis in an emergent virtual realm. Licentiously combining Kohn's semiotic approach with Ingold's and Bird-David's (1999) perspectives on continuous relational becoming, I explore how Luangan spirit communication inheres in life in the material environment and worldly existence, yet also serves to elude its formative influence. I propose that Luangan spirit communication maintains a virtual, open-ended domain of possibilities, reminiscent of the diverse rainforest environment itself, including its plural life forms and varied opportunities for sustenance. As such, it offers hope for refiguring lives and fates, for managing and understanding life conditions and events beyond human control and transparency. Important to note is that spirit communication does not simply and indiscriminately represent phenomenal reality, but essentially expresses vital human (and sometimes more-thanhuman) concerns of ongoing liveability in the world. Its nature is essentially 'agentive'. Luangan dealings with spirits seem to be mainly motivated by negotiating conditions beyond human control and purposive agency, influencing what I have called the non-human backdrop of human existence' (Herrmans 2015: 247). Sometimes, as in Tanto's case, they may express a sense of disquiet or 'being out of place', either literally or figuratively, which here applies to both humans and nonhumans; sometimes, as in rituals, they form outright attempts to alleviate debilitation and regain health or agency.

\section{Change and continuity in Luangan relational landscapes}

The Luangans are a Dayak (indigenous Bornean) people who live in the mountainous interior of Borneo's southeastern corner, in the border area between the provinces of East and Central Kalimantan. Even though they number more than 100,000 people, they are politically marginalized and little known, reflecting the fact that they live dispersed in small shifting cultivator communities across a vast upriver area, at a remove from administrative centres. Being divided into many subgroups, they are also weakly integrated internally and little mobilized ethnically. Their main basis of commonality, and the likely source of derivation of their common ethnonym, is a shared ritual tradition originating from the central parts of the Luangan area, especially the upper Teweh river region in Central Kalimantan, and a corpus of mythology associated with this area (see Herrmans 2015: 30). 
Most of my fieldwork, conducted over a period of more than two decades between 1993 and 2017, was done in the central Luangan area, and the greater part in Sembulan, a small village on the East Kalimantan side of the provincial border, a day's walk from the mythical homeland. ${ }^{2}$ This is the village where Tanto lives, and from which all examples presented in this article are drawn. Until recently, much of the central Luangan area was only accessible by foot or along logging roads, as local rivers are shallow and unnavigable for most of the year. Remoteness, residential dispersal, and a comparatively strong maintenance of their 'religious' tradition has earned the inhabitants a reputation as 'undeveloped' and 'isolated' and subjected them to various state development schemes, including residential concentration and resettlement. Especially since the beginning of political decentralization in 1998, they have also been subjected to proselytization efforts by Protestant missionaries, who generally condemn 'animistic' practices.

Since adherence to an officially recognized world religion is deemed obligatory in Indonesia, pressure to convert to one is high and often forms a condition for attending higher education. Today about half of the Luangans have become Christians, whereas the others identify as Kaharingan, a term for indigenous religion in South Borneo. ${ }^{3}$ Even so, Luangan adherence to Kaharingan is among the highest of all Dayaks, and associated rituals remain exceptionally common.

For the Luangans I worked with, the rainforest environment forms the basis and very substance of their relational ecology. Most of them until recently subsisted on shifting cultivation of rice and other food crops, complemented by hunting, fishing, and the gathering of forest products, as well as growing rattan to sell. In the past, they lived dispersed in the forest, shifting residences between frequently moved multi-family houses and single-family farmhouses located in their swidden fields. Even though nucleated village settlement was ordained already by the Dutch colonial government, and later by the postcolonial administration, many people until recently continued to reside predominantly in farmhouses in the forest, often located several hours' walk from the village. This settlement pattern allowed for considerable personal and family autonomy, and, along with egalitarianism and inclusive classificatory bilateral kinship, contributed to an 'open-aggregated' social structure marked by flux and flexibility (Sillander 2011).

The Luangans' residential and subsistence pattern has also promoted close relations between them and the various life forms with which they share this environment. Luangans enter the forest both to 'harness some of its plenty' (Kohn 2013: 95) and to negotiate human health and well-being with a multitude of other-than-human selves on whose goodwill they depend. Like for their Meratus neighbours, the forest is 'a social and productive space' for them, replete with traces of past human activity and manifestations of nonhumans (Tsing 2005: 175). It provides much of the form and content of their ritual activities and representations of the unseen world, as exemplified by the many miniature spirit houses constructed for all rituals from a rich variety of forest trees and plants, which index the locations and habits of the manifold spirits of the forest environment.

When oil palm companies entered the area in 2009, many people held out at first and refused to sell land to the companies. However, most eventually felt that they had no choice but to sell. If they did not, someone else would; since land rights, which are established through the first clearing of forest for cultivation, were until recently undocumented, and are inherited bilaterally and hence often held in 
common by many people, individuals cannot guarantee effective control of their land ownings.

Built at roughly this same time were many of the roads that now link most central Luangan villages with each other and with inland and coastal centres. A number of villages soon became all but deserted as people started to build new houses along the roads, partly to safeguard whatever forest was left from being grabbed by outsiders, or locals aiming to sell it, but also, as they said, just to be where the action was. The roads have not only enabled easier movement for the inhabitants, but also opened up the area for outsiders, including travelling merchants, missionaries, bandits, and forest resource extractors of different kinds (see Tsing 2005: 38). While people used to walk long distances to their fields or neighbouring villages along winding forest paths often overgrown with thorny rattan vines, crossing rivers and streams, stopping to harvest some fruit on their way or follow the tracks of a wild boar or deer, today they rarely walk far in the forest. Instead, they mainly travel by motorbike along dirt roads - slippery and muddy when it rains, scorching hot when the sun is shining - often surrounded on both sides by endless rows of young oil palms.

It is not only the contours and much of the phenomenology of the natural landscape that has changed with the arrival of oil palm cultivation, but also the Luangan social and moral economy. As locals conceptualize it, sharing and solidarity between kin and neighbours have drastically decreased in just a few years. For example, game was until recently widely shared within communities, and minimally with neighbours and close relatives, but today practically all meat obtained through hunting is sold, even to close family members. Although the Luangans have a long history of selling forest products for trade (especially rattan and resins), villagers perceive that oil palm cultivation triggered what can be described as a shift from a 'market-as-opportunity' to a 'marketas-compulsion' state ( $\mathrm{Li}$ 2014: 6), transforming villages from being largely subsistencebased to having market-based economies. While some people have hurried to exploit whatever resources are left - making larger swidden fields than ever before, using chainsaws bought with money received in compensation for land, and opportunistically collecting whatever forest products may have a price - many have become increasingly 'lazy', as they say, and dependent on store-bought food.

Tanto's story of his encounter with the wok, like other similar stories, illustrates the ambiguity that characterizes Luangan relations to the transformed environment today. Exemplifying something of an experiential aporia, an insoluble impasse that cannot be 'determined, categorized, or placed within a meaningful order' (Bubandt 2014: 6), it can be read as a reflection of the hesitancy and uncertainty that many Luangans feel, not quite knowing how to go forward or steer their life courses. While many have embraced the opportunities of capitalism, welcoming the 'progress' (I. ${ }^{4}$ kemajuan, a major catchword in Indonesian state discourse), supposed freedom, and inclusion engendered by roads and money, there is simultaneously an outspoken ambivalence and uncertainty about future livelihood opportunities (see Chao 2018). This is not the least the case because the oil palm plantations offer few work opportunities for Luangans; managers favour 'migrant workers over "locals", because migrants, being totally dependent on plantation work, are 'more easily disciplined' (Li 2014: 170). Moreover, oil palm crops, from which Luangans receive a 20 per cent share on land sold, have already been shown to occasionally fail, or sometimes they cannot be harvested at all owing to difficult transport conditions. The wok, as both image and agent, thus evokes a more widely felt incertitude or sense of 
loss brought about by the scale and pace of change in the physical and social landscape.

And yet what has struck me during recent visits to the field is effectively the lack of change vis-à-vis the quantity and quality of Luangan relations to many of the other-than-human 'selves' with whom they share their environment. This is especially poignant when considering the far-reaching changes that have occurred in other areas of their social life. This persistence pertains especially to belian healing rituals, which continue to be performed with undiminished frequency.

Luangan shamans often describe belian rituals as 'paths' along which offerings of respect and food are brought to the spirits. Like the paths along which they used to walk in the rainforest, which quickly become overgrown with tangled secondary growth if not actively used, the paths that traverse Luangan ritual landscapes - paths used to communicate with spirits - are created and maintained through continuous usage. Recurrent rituals invoke and enact relations with a diversity of nonhuman beings in the environment, superimposing a ritual landscape upon the natural landscape. During my early fieldwork in the 1990s, belian rituals occurred roughly every second night, and there were often several rituals going on simultaneously. People described themselves as 'practising belian incessantly', not without a sense of pride. In Sembulan, with a population of about ninety inhabitants, there were fifteen actively practising shamans. The abundance of healing rituals could only partly be explained by a lack of modern healthcare in the area, with rituals often also being arranged for rather minor illnesses, or just as a precaution to prevent future illness.

There is now a shortage of shamans in some villages, since many of the older shamans have died and younger people reportedly are no longer willing to go through a period of apprenticeship that may last several years. Yet despite this, the profusion of rituals has not diminished since the 1990s, at least not among non-Christian Luangans. On the contrary, in some areas ritual activity has even increased, with rituals being extended into several month-long affairs; this largely reflects gambling conducted during the rituals, which contributes to their funding and thus encourages their prolongation (see Herrmans 2017). When I last visited Sembulan in 2017, three belian rituals were performed simultaneously, with one shaman simultaneously conducting two of them, causing people to joke about the busyness of shamans and anthropologists alike. In a village of the central Luangans' Benuaq neighbours, a thanksgiving ritual had gone on for over three months, with no end in sight. Today, the practice of belian, and especially certain activities in them, such as offering food to spirits inhabiting particular sites in the local landscape, or searching for lost souls in it, continues to offer a means to virtually maintain relations with the plurality of beings in a local rainforest environment which in many locations no longer physically exists, and from which many Luangans have become increasingly estranged in their daily lives.

It is through situated stories, presented somewhat impressionistically, that I will proceed. I first discuss omens and dreams as means of communication across human and nonhuman boundaries. I then move on to consider spirit encounters in the transformed environment, elaborating on Tanto's encounter with the wok. Finally, I turn to rituals to examine how they maintain relational landscapes through which humans and nonhumans are co-constituted. In presenting these stories, I move back and forth in time between my initial fieldwork in the 1990s and my more recent fieldwork. 


\section{Dreams and omens as signs of a future possible}

In July 1996, Ma Sarakang, a middle-aged shaman, decided to join me and my fieldwork partner on a trip downstream to Tenggarong, the capital of the formerly independent Sultanate of Kutai located near the east coast of Borneo. We had planned the trip for some time and had, after some effort, managed to arrange a lift with a truck from the logging camp near Sembulan for the first step of the journey. However, in the morning of the day of our agreed departure, Ma Sarakang came to tell us that we had to postpone the trip. During the night, he had had a dream in which someone offered him an ensem fruit (a species of sour wild-growing mango). He interpreted this as a sign of impending danger of some sort, suggesting our departure on that very day was inauspicious. Luckily, we managed to arrange a new ride for the next day. When we on the evening of that day finally arrived in the downstream village of Lambing, a departure point for river ferries to Tenggarong, we stopped for the night by the house of Temen Dotun, a well-known ritual specialist, with whom I often stayed on my journeys downstream. Ma Sarakang then seized the opportunity to ask Temen Dotun for his opinion about how to interpret the dream. After much pondering back and forth, Temen Dotun came to the conclusion that, as the destination of our journey was a city downstream, rather than a forest location, there was no danger in embarking on it. He did, though, advise Ma Sarakang not to walk around in Tenggarong when we got there, but always to use some form of motorized transportation.

Ma Sarakang stayed in Tenggarong for just a couple of days before he rather abruptly decided to return home. Owing to some business opportunities that had presented themselves while he was in town, however, he planned to return to Tenggarong as soon as possible. After a few weeks, as he was about to leave his home village again, he had another dream, which this time involved him falling while walking in the forest. This forced him to reschedule his departure once again. Somehow, the dreams suggested, his soul (juus) was repeatedly caught up in entanglements of its own.

Luangans regard dreams as reflections of the experiences of the soul. During sleep, a human's soul separates from the body and wanders about, interacting with other beings, including ancestors, other spirits, and animals (often perceived to be possessed by spirits). Sometimes such a wandering soul may be mistaken as prey by a spirit out hunting and be hit by a blowpipe dart, causing soul loss or soul weakness in the dreamer. If the soul accepts food from someone in a dream, this is interpreted as exposing its 'owner' to illness, as it exhibits a state of excessive sociality with spirits, blurring the boundaries between them and human beings. Similarly, falling in a dream might imply that the soul is being drawn into the spirit realm; like other instances of dreams of spirits, this is often interpreted as ultimately reflecting rejection of proper sociality between humans (tapen), and it suggests that an inverse relation between human-to-human and human-spirit interaction pertains in some contexts.

In shamanic chants, the Luangans ask for 'good dreams and auspicious omens' (upi buen, baya nado). Fundamentally, what they then request are good relations with spirits, meaning 'proportional' relations, showing a balance between proximity and distance (see Remme 2016; Willerslev \& Pedersen 2010). In the Borneo ethnography, interpreting dreams and omens has often been described as an anxiety-ridden and allconsuming enterprise (Amster 2009; Nieuwenhuis 1904-7; Rousseau 1998: 67-74). To cite Matthew Amster (2009: 314) on the Kelabit, 'virtually all dimensions of the physical and social world were potential sources of fear and spiritual concern'. (The Kelabit are all Christianized today, hence the past tense.) The 'need to pay constant attention' to 
dreams and various signs of spirits in the environment - prototypically represented by the flight of different species of birds - and the limitations on activity imposed by such a 'spiritual regime' have even been presented as a reason for their conversion to Christianity (Amster 2016: 208, 211). However, among the Luangans, dreams and omens are less experienced as a source of fear and anxiety than they are seen to provide information that is otherwise hidden or unknown. Contrary to dominant views, omens and taboos are not all-restricting and anxiety-inducing but also enable a sense of control and of being at ease (see Howell 2012: 141-2). Like the Rmeet of Laos, Luangans use 'dreams [and omens] to determine their current relations with local spirits'; dreams and omens thus serve as means through which spirits 'make their needs known' (Sprenger 2010: 59). Consequently, dreams and omens are not so much signs of predetermined futures, or commentaries on the past, as tokens of the current status of one's relationship with nonhuman beings. Perhaps most importantly in the Luangan case, they point to the need for attending to the relations with these other selves, a requirement reinforced by the mythological notion that spirits and animals are the elder siblings of human beings, a condition which by itself calls for reciprocal relations (see Herrmans 2015: 229-33).

Especially before embarking on a journey or opening a new swidden field, interpreting dreams and omens may form a crucial means to not only predict but also affect the outcome of such enterprises. As signs, omens and dreams reveal what has not yet happened and thus allow for reorientation. As Kohn states, "[S]igns, as "guesses," re-present a future possible, and through this mediation they bring the future to bear on the present' (Kohn 2013: 207). The successful outcome of such enterprises is in this respect conditional on being 'perceptually attuned' to signs of other-than-human selves in the environment (Ingold 2000: 290). While dreams, omens, and other signs from spirits may occasionally be experienced as debilitating, they simultaneously also entail a promise of agency, allowing for a re-presentation of relations, and hence for a sense of direction, and some measure of predictability in a world that is forever uncontrollable and unforeseeable.

The most effective way to affect human-spirit relations among the Luangans is to provide offerings of different sorts, especially food for the spirits, among them the masters or lords (tuhan) of dreams and omens, said to have once been human beings. As related in the Luangan origin myth of omens, such offerings, which are routinely given during rituals as a preventive measure, 'forestall depredations and ensure ... good offices' (Hopes 1997: 23). In effect, they do this by confirming human-spirit sociality, a condition that in its own right furthers good relations and, accordingly, good omens. Consequently, considerable time and effort are put into preparing the food for offerings and manufacturing trays or 'altars' upon which this food is displayed, with the sheer number of such paraphernalia reflecting the diversity of spirits negotiated with during each ritual.

Equally important, however, is to maintain boundaries, to keep the spirits at a certain distance or in place, away from human beings. This is required because spirits may bring not only fortune and prosperity, but also illness and adversity, such as through soul theft. Born out of the incestuous union between the first human being and his daughter, according to the myth of their origin, spirits are often immoral or deceitful and prone to misbehaviour. The aim in communicating with spirits is hence to both maintain and avert relations with them. The emphasis varies with the context and spirit, but interacting with spirits is essentially an ambiguous endeavour that requires both integrating and distantiating efforts. 
When Luangans walking in the forest come upon an omen bird flying from the right to the left (the left being associated with death and adversity), they stop to carve out a small figurine of wood resembling a human being, which they spit on and give to the spirits as a substitute for their souls. As usual, they do so with the intention of both creating a connection and breaking that connection. Similarly, ritual offerings placed in small spirit houses given to the spirit masters of dreams and omens, along with similar offerings dedicated to the multitude of other spirits, are offered both to please them and make them act supportively, as well as to keep them from interfering, to make them return to their houses and locations.

While walking along the forest path on our way to catch the truck downriver, Ma Sarakang mumbled Islamic prayers, even though he was not a Muslim, to ensure us a safe journey. These prayers he considered especially appropriate as we were travelling downstream, into Muslim territory. (Later, on the river ferry, he sat reading an Islamic prayer book. This activity, however, probably served to influence his fellow passengers more than the spirits.) Successfully interacting with other selves, trying to know and please them, is conditional upon considering, and temporarily adopting, their viewpoints. Travelling downriver, Ma Sarakang attended to the different perspectives of downriver seen and unseen inhabitants, including their religion, but also their ways of moving in the world (by using motorized transportation, as recommended by Temen Dotun). Doing so served both as a strategy of attunement to the downriver environment and as a protection against its influence.

\section{Movement in the landscape: relation and alienation}

When I asked Tanto what the wok he met on the road wanted, he did not hesitate with his answer: 'To eat, as spirits always do!' Food in dreams and in waking life indexes social relations, and in this case it perhaps indicated a request for compensation of some sort, as the wok was what he called a 'forest spirit'. Moreover, as Tanto emphasized, a wok could eat human beings. It is worth noting that he had encountered such beings not just once, but several times in the past year, always on the road and several times in the vicinity of the oil palm company camp where the plantation workers lived. Once when driving back from a shopping trip to another neighbouring village with two of his friends, he heard the sound of some young people talking, thinking that they were out cavorting in the dark. But then suddenly a ghastly-looking wok appeared, a female spirit with a lacerated face and an open hole in her chest, lurking on the company road going through the head camp, a short cut home for Tanto. Instead of holding him back, this wok pulled his motorcycle along at great speed while disabling the brakes, taking him on a crazy, horrifying joyride for what he estimated to be several kilometres. Another time, when he had gone to make a phone call up on a high hill near the village, the only place nearby where one can get a phone signal, he first heard a strange sound, as if someone was striking a hollow tree, and then he saw another wok, just standing there. Terrified, he switched off his phone and ran back to the village. Yet another time, on a dark rainy evening, as he and a friend were on their way home from celebrating Christmas in the village of Suakong, close to the district capital where they went to school, they were suddenly blinded by a bright light. The light turned out to emanate from a kuntilanak, a kind of vampire ghost, well known from Indo/Malaysian horror movies, often portrayed with long black hair and wearing a white robe, in this case with eyes hanging out of her sockets. This terrifying spirit then chased them all the way back home. $^{5}$ 
In all these cases, either some form of modern machinery was involved or tampered with (see Bovensiepen 2009: 333) or there was a correlation to recent environmental or cultural changes: for example, taking place on the road near the oil palm estate or, notably, when Tanto and his friends were out shopping or participating in Christian Christmas celebrations. Although Tanto himself did not make any overt connections in this regard, the wok (and kuntilanak) clearly seemed to be semiotically aligned with this transformed landscape: a forest spirit, out of place, looking for relations, or, as Tanto expressed it, just out to scare. Similar to the Thai horror films and ghost stories described by Andrew Johnson (2013: 300), Tanto's stories demonstrated a link between 'the idea of (and desire for) progress and the uncanny'. (All the spirits Tanto met were female, simultaneously attractive and terrifying.) As in the Thai films and stories, things which appeared modern and prosperous were in fact shown to be 'tainted with foreign presences' (Johnson 2013: 300).

Cheryl McEwan describes how ghosts flourish in rapidly modernizing societies, being 'products of complex engagements with rapidly changing circumstances' (2008: 34). In Indonesia, reinvented ghosts and spirits have been shown to 'articulate and haunt a new regime of life' (Bubandt 2012: 17). Since the fall of President Suharto in 1998, and the processes of political decentralization, heightened resource extraction, and ethnic violence that followed, an increase in suspicions of witchcraft and encounters with terrifying 'modern' spirits or monsters (such as Dracula) has proliferated throughout the archipelago (see Bubandt 2008; Siegel 2006). In Andrew Beatty's words, such spirits, or the evil they represent, are 'a phenomenon of dislocation, being out of place, no longer at home in the world' (2019: 91).

Like the bodies of 'monsters' theorized by Jeffrey Cohen (1996: 4), the wok Tanto encountered on the road incorporated 'fear, desire, anxiety, and fantasy'. A forest spirit but in the shape of a 'monster', as seen in popular horror films and soap operas shown on TV (see Bubandt 2012), the wok materialized the ambivalence felt towards an imagined future and a landscape 'haunted' by such a future (Gan, Tsing, Swanson \& Bubandt 2017: G2). Contrary to many other spirits with whom Luangans interact, who may appear frightening at times but with whom they nevertheless regularly and often voluntarily engage in relations, the wok, like the various other kuntilanak-like spirits that Tanto and his friends encountered on the road, appeared alienated from human sociality, craving not only food from human beings, as spirits do, but also to 'eat human beings'. If not necessarily entirely 'beyond communication', like the Thai spirits described by Johnson (2013: 309), exactly how to communicate with them ultimately remained unclear. Instead of presenting the wok with a small human figurine, as he might have done if he had encountered a bad omen in the forest, Tanto thus tried to speed away on his motorbike as quickly as he could.

Etymologically speaking, a monstrum is 'that which reveals', 'that which warns' (Cohen 1996: 4). An 'embodiment of a certain cultural moment - of a time, a feeling, and a place', a monster inhabits 'the gap between the time of upheaval that created it and the moment into which it is received'. Always a displacement, signifying something other than itself, it is a projection existing 'only to be read'. It is from that uncertainty - the gap between representation and that which is represented, or the différance in Derrida's terms - that the monster gains its vitality (Cohen 1996). Refusing to fit within neat or stable categories, the wok encountered by Tanto embodied a more widely felt Luangan apprehension, an uncertainty and aporetic sense 'of not knowing where to go' (Bubandt 2014: 6). One could say it emerged out of that sentiment of 
being without a place caused by accelerated change and the transformed environment shared by humans and spirits. At the same time, by tampering with Tanto's motorbike and chasing him and his friends, it was experienced as more than a mere projection, forming an agent and a warning with potentially very real consequences.

Signs from the spirits should be taken seriously (which is not to say that Luangans may not choose to ignore them, taking a chance that nothing will happen). As Kohn asserts, '[O]ur lives depend on our abilities to believe in and act on the provisional guesses we make about the motivations of other selves' (2013: 118). For Tanto, this was proven true by what happened to the Banjarese traders. As outsiders to the area, they were presumed to be ignorant about how to read the environment for other-thanhuman signs and were apparently not protected from their implications through their Islamic faith alone. At the same time, what protected Tanto was probably not his ability to interpret a message that remained obscure throughout, but a more general knowledge of or 'belief in' spirits and how to 'read' the landscape for their semiotic presence, which was lacking among the Muslim Banjar traders. Or, put differently, what presumably and for the time being protected him was his ability to recognize the wok as a self - a subject, a you - which would thus, hopefully, enable himself to in turn be recognized and afforded such status by the wok.

Tanto may have also been protected by a more general commitment to relationality. The frequency and inclusive character of Luangan healing rituals, which always address both known spirits and spirits with no known names (ye beau tau aran), serve to provide a measure of protection that extends beyond the context of particular rituals and identified addressees. Even if there was no direct attempt to communicate with the wok in Tanto's case (such as through a ritual arranged as an immediate consequence of the encounter), his history of involvement in belian curing by itself provided a protection of sorts, not least by implicating a commitment to a continued relationship with spirits. Proposedly, it was a mutually constitutive responsive attitude, created through such a history of ongoing practice of interrelation, which protected him and other Luangans, making both humans and spirits open to the possibility of a re-presentation of reality. In a sense, then, it was Tanto's relationship with spirits more generally - and the capacity of rituals to act as a means to maintain such relations, and thus keep spirits 'in place' that protected him.

\section{Rituals as relational landscapes}

When Tak Hai dreamed in 1997 that her granddaughter had fallen into a small stream while taking a bath, a belian healing ritual was quickly arranged. The ritual sought to retrieve the child's soul from various spirits, especially from juata, a heterogeneous type of water spirit inhabiting various places in rivers (rapids, whirlpools, river mouths, bathing spots) and other water localities (ponds, springs, puddles), as well as celestial lakes. Juata is not only multi-local, residing both upriver and downriver, and in heaven, but also an inherently polymorphous entity, which may manifest as a water dragon, crocodile, crab, frog, turtle, snake, fish, leech, and so on. In addition, juata can take human form, and is in this guise often regarded as the master of the others.

Small baskets with offerings were presented to juata, containing not only rice, meat, an egg, and some blood, but also mimetic images of juata itself, small figures of the spirit in all its different shapes made of rice paste. In addition, and like other categories of spirits, juata received a variety of small houses to dwell in, such as one made of a particular species of fern that grows on river banks, and another made in the shape of 
a raft, all evocative of the spirit's habitats or habits. One house was made of a species of cultivated yellow bamboo associated with royalty and downriver sultans, illustrating a prominent association between juata and the downriver world. Often considered to be Muslim, juata should preferably be offered sacrifices not of pigs, but of goats or chickens instead (although a white pig may sometimes be acceptable).

The ritual entailed travelling into a landscape that extended well beyond the local milieu, connecting upstream and downstream, heaven and earth, and thus also cosmology and politics. Through his chanting, Ma Buno first traversed the local area, bartering with upstream juata dwelling in rapids and river pools, cajoling juata of a local waterfall to return the child's soul, asking juata of the village's bathing place to withdraw. Bringing offerings to juata of the Telakei river of the Pasir district (a downriver region whence the Luangans brought rattan seeds to initiate rattan cultivation in the early nineteenth century), he then went further afield, approaching juata at downstream river mouths and even as far away as the sea. Bringing along fishing equipment, some knives, and an axe, he then travelled up into the sky to a celestial river pool inhabited by Bua Ore Ani, a crocodile spirit known to frighten children, in order to fish for the child's stolen soul and to intimidate the spirit with his weapons. 'Listen, you juata down here', he sang, 'don't you frighten children, and you juata up there, don't you frighten the moon'. (The waning moon is an inauspicious condition and a potential cause of misfortune, or even death.) Other spirits, including ancestors, local and non-local forest beings, including those of other ethnic groups, were encountered along the way and were similarly offered food of various kinds, Ma Buno attending to their particular points of view in so doing.

Reflecting and transcending the formative influences of conditions in the world, the spirit realm visited and evoked by Ma Buno formed a virtual sphere that was emergent from Luangan life experiences beyond it. Like the Runa realm of spirit masters, this spirit realm may be seen to be characterized by an 'effortless propagation' and 'play' of form; conceptions of spirits and modes of communication flexibly draw on the affluence of forms across time and domains in the natural and social environment, in a manner akin to processes of condensation and displacement in dream language (Kohn 2013: 153-60). Many practices now discontinued in the sphere of human-tohuman interaction are preserved through ritual activities that follow the patterns of past forms of life and sociality in the natural environment, or the (in many ways inseparable) cultural and political human world. Forest life and subsistence strategies, social relations with kin, neighbours, and non-locals of various sorts, of nearby or distant communities, of past and present political regimes, provide both the content and form of the ritual activities. In them, as well, planting rice with sticks, blowpipe hunting, fishing with baskets and nets, visiting, hosting, raiding, bartering, sharing, exchanging, and so on, are generic forms of action of which the various ritual activities represent so many variations.

Like its Runa counterpart, the Luangan spirit realm manifests a curious relationship to history. It is at once detached from or 'beyond' history and assembled out of it, among other things by being significantly 'colonially inflected' (Kohn 2013: 214). It is a realm where tribute is still paid to spirit masters, even though the practice compelled by coastal sultanates has long been discontinued, a place where long-dead head-hunters from neighbouring groups roam and intermingle with Muslim prophets, colonial-era officers, regionally and locally prominent shamans, community leaders of the past, and mythological heroes. It is the principal domain where the Luangans seek to access the 'accumulated riches of the powerful', an endeavour nourished by the 'long and layered 
history of deferred desires' that centuries of political marginality have generated (Kohn 2013: 185). Entering this realm means entering a virtual realm of abundance, a 'domain of circular causality' where 'things that have already happened have never not happened' (Kohn 2013: 181). In this regard it strongly resembles another historically embedded dominion of spirits emerging from political marginality: the Realm of the Diamond Queen of the Luangans' Meratus Dayak neighbours (see Tsing 1993), the name of which derives from a mythological figure associated with a Javanese kingdom, who brought prosperity to the previously destitute Meratus mountains.

In 2017, when a man dreamt that his grandson had fallen into a river, Ma Buno performed another ritual addressed to juata. Again, offerings of respect and food were brought to the various juata in the local landscape and beyond, as well as the plurality of other known and unknown spirits, along well-trodden ritual paths. Diverse ritual offerings and paraphernalia made of various plant materials were assembled outside the house and given to the spirits. Verbally and materially traversing a spiritual landscape seemingly unaffected by oil palm cultivation and the ecosystem simplification caused by such monoculture, Ma Buno strategically engaged the forest ecology of selves by entering 'forest form', in its diversity and complexity, as a means not only to access its riches, but also, in Donna Haraway's words, to 'sustain reworlding' (2015). Negotiating with spirits through belian healing rituals implies embracing a viewpoint that encompasses a multiplicity of perspectives (see Viveiros de Castro 1998) and attempting to find mutuality in this plurality through a responsive orientation that affirms relationality as a precondition for well-being (see Bird-David 2006). In this way, the ritual manifestly illustrated a form of sympoiesis, or 'making-with' (Haraway 2017: M25), whereby human-spirit relations, here cast as kin relations, were reconstituted through the particular form of semiosis that ritualization entails.

At the same time, and again, the ritual, and the offerings presented, served to maintain boundaries, to keep the spirits in place, away from human beings, to prevent transgression of ontological boundaries that might debilitate human vitality and agency. Even though predicated on relationality and co-constitution, the Luangan ritual endeavour of securing human well-being requires the continuous balancing of separation and integration, of averting and affirming relations with spirits.

The forest groves (simpung) in the vicinity of Luangan villages that have been salvaged from swidden cultivation - and from oil palm plantations today - serve as a case in point. These small patches of primary rainforest, usually between one and a few hectares in size, afford a place of refuge for spirits and animals (gibbons, hornbills, etc.) and offer a reserve for primary forest plants gathered for food or used as ritual paraphernalia. By providing a place to live for spirits, they prevent them from entering human habitations. At the same time, they are regularly visited by shamans looking for lost souls or signs of where such souls may be hidden and with the intention of bringing offerings to the spirits dwelling there. As several shamans told me, when conducting rituals they 'cannot not go to forest groves', implying that this locale holds a special significance and forms a near-mandatory stop in shamanic travel. The concentration of spirits, close to villages, yet away from them, compelling association, yet enabling disassociation, seems crucial for allowing for the cogent maintenance of virtual relational landscapes (while the groves themselves are indispensable for enacting rituals by providing the material for the ritual paraphernalia).

When selling land to the oil palm companies, Luangans usually make an exception for these forest groves, just as they refrained from making swidden fields in them 
before. As Ma Lutar, a former village leader, told me, he consistently interfered when people had tried to sell off such land. Without such refugia, places of 'resurgence' that 'forge assemblages of multispecies livability' (Tsing 2017: 54), relations with spirits become unmanageable. Like similar tree reserves among the Iban of northern Borneo (Wadley \& Colfer 2004), the groves also mark significant historical events and thereby reproduce historical consciousness of past human trajectories within the landscape. The forest groves are especially important today as remnants and exemplars of the dwindling rainforest biotope, which forms the backdrop and substance of so much of the historically generated spirit realm, thus sustaining preconditions for 'ongoingness' (Haraway 2015) in this relationally constituted local ecology of selves.

\section{Conclusion}

Surrounded by oil palm plantations, the forest groves today stand out as small forested islands, forming tokens of a complex tropical ecology that either has given or is about to give way to a much simpler one. As a refuge not only for spirits but for other lifeforms as well, these forest groves may be seen as images of a relational ecology increasingly suppressed by the forces of capitalism. Similarly, belian rituals represent virtual means to maintain relational landscapes through which Luangans 'continue to engage the forest's ecology of selves in their own search for sustenance' (Kohn 2013: 193), even as the forest itself is about to disappear. 'Sustenance' may here be taken to refer both to the opportunistic ways of making a living in the forest that has characterized Luangan subsistence and to similarly flexible and multiplex ways of utilizing kinship and other social relations in this pursuit. Seen in this way, the persistence and lack of change characterizing belian healing rituals can be interpreted as an ontological choice, to keep the rituals open to interrelation with the many sorts of selves the Luangans share their environment with, and to continue to employ a modus operandi that is attentive to the unpredictability and inconclusiveness of the reality represented.

The spirit realm encountered during the shamans' travels is a realm where the rainforest is still intact, and where relations with a plurality of other-than-human beings, emergent in and connected with particular features of that landscape, can be both maintained and forestalled. The profusion of Luangan rituals, the plethora of spirits addressed in them, and the diverse modes of human interaction with these spirits in and beyond them mirror the proliferation of opportunities in forest life more generally, as well as the unfettered conditions for undiminished possibility that such plurality entails. A central rationale for this unbounded and elastic incorporation within the spirit realm is stretching the virtual space of possibilities that it holds.

Yet, this is not the whole truth. While belian rituals have remained surprisingly vibrant and 'unchanged' in many Luangan villages, there has also been an upsurge in Christian conversion in recent years. This is partly a result of increasing mobility as villages have become connected through roads, which has brought more missionaries into the area, often with a rather fundamentalist bent. In combination with greater income from land sales, the new infrastructure has also increasingly allowed parents to send their children to secondary school in the district capital, forcing the latter, at least nominally, to convert to an officially recognized religion, mostly Christianity. For some Luangans, as for the Urapmin of New Guinea studied by Joel Robbins, it seems that 'Christianity has provided them with the conceptual and ritual means to disassociate themselves from their land and in so doing has been crucial in bringing them to the point at which they can imagine themselves able to barter their territory for 
the promise of a different kind of life' (2006: 66). Along with Christianity, they acquire an ontological-ideological charter for a de-localized world-view, facilitating adoption of a more detached and instrumental relation to the landscape and its forest ecology of selves.

The wok standing by the road, interfering with the traffic of motorbikes and trucks, serves as a reminder that such a transition may not be as smooth as some would hope. This quandary is also experienced by some of the immigrants brought in to work at the oil palm plantations, who mostly hail from the eastern Indonesian island of Flores; when they become severely ill, finding that modern medicine lacks answers on how to deal with such 'local' diseases, they desperately seek out Luangan shamans. Similarly, for young Luangans who become possessed en masse by spirits while away from their homes, attending high school in the district capital, engaging with the local landscape is not always a matter of choice, or associated with any degree of certainty, for that matter. While back in the 1990 s riding a motorbike was seen as a safety measure, which could protect Ma Sarakang from spirits while he was in town, today all sorts of motorized vehicles, along with other technological devices, have become part of the distributed agency of spirits, causing a new sort of vulnerability. Modelled on figures seen in horror movies on TV, spirits may assume new shapes and behave in unexpected ways. Finding ways to act upon the signs of other selves is thus perhaps more urgent than ever, and dependent upon recognizing selfhood as relational in the first place.

This, I have argued, is a process demanding both attunement to a world-in-formation and engagement in the semiosis of virtuality. For many Christian Luangans, who continue to be influenced by the pre-Christian ontology, this means that they return to belian rituals when they become seriously ill. (Some also 'jump between religions', as they say, going with what works best in the situation.) The resilience of belian rituals is based primarily not on their capacity to reconstruct the past (whether as landscape, tradition, or relations with spirits), but rather upon their ability to refigure the future. Eclectically harnessing the forms of the past and the present, Luangan rituals form a virtual space of continuous becoming. Rather than rituals representing a form of 'deference', to use the terminology of Maurice Bloch (2005), who argues that the attraction of ritual continues when everything else seems to be changing primarily because of the authority of the precedent, I argue that the attraction and persistence of Luangan rituals above all reflect their capacity to remain open to a world-in-formation. Their proliferation is not a question of shamans reconnecting with or re-creating the past - although this may often be vital among people confronting capitalist expansion (e.g. Buyandelger 2013: 10-12) - or a matter of merely dealing with the unpredictability caused by such expansion, but a continuous negotiation of a 'future possible' in which the endemic uncertainty of life - its very contingency - is what forms the possibility for its transformation. In this interpretation, the continuous appeal of belian rituals is tied to their ability to incorporate uncertainty and the unexpected in their very structure.

\section{NOTES}

Financing for this research was granted by the Academy of Finland (grant 1276848) and the Kone Foundation. This article was significantly improved through the comments of two anonymous reviewers and the Editor. I also thank Kenneth Sillander for his insightful comments and suggestions.

1 'Form' is one of the most intriguing concepts of Kohn's (2013) 'anthropology beyond the human'. It is central to semiosis in the broadened Peircean sense he envisions, which encompasses the 'nonsymbolic representational modalities' shared by humans and other living beings. The concept is difficult, he admits, because it is neither concept, nor strictly a thing, yet 'real'. What he essentially is getting at are patterns, 
regularities, and habits of phenomenal entities. Form constrains and enables thought, and is propagated by living beings through semiosis, significantly through nonsymbolic representational modalities. The concept suggests some important ways in which the material world affects humans, as well as other living beings, and through which higher-order symbolic domains such as spirit realms 'emerge' from it through pattern propagation, yet also acquire a 'virtual' character and a degree of independence from it. My analysis draws on Kohn's notions both of the embedded nature of semiosis and of the emergent qualities of symbolic realms, and especially his understanding of how semiosis involves self-making in a 'futuro mode of being' whereby representations elude some of the constraints imposed on phenomenal reality.

${ }^{2}$ Fieldwork in the central Luangan area was conducted for six months in 1993, twelve months in 1996-7, and for a total length of approximately eight months during six shorter field trips made between 2007 and 2017. All periods of fieldwork were conducted together with Kenneth Sillander of the University of Helsinki.

${ }^{3}$ Kaharingan was notably accepted as a religion, as a variety of Hinduism (labelled Hindu Kaharingan), in Indonesia in 1980, after a long struggle led by the Ngaju Dayak in the province of Central Kalimantan (Schiller 1997: 109-31). In East Kalimantan, however, the Muslim-governed local government has not recognized this status and Kaharingan still holds the lower status of 'beliefs' only (I. kepercayaan - see note 4).

${ }^{4} \mathrm{I}$. indicates Indonesian. Other, unindicated, words in italics are in Luangan.

5 Tanto was not alone in encountering such spirits on the roads. On Facebook, stories abound of outsiders entering the area and meeting terrifying spirits on the road. A Luangan woman who had moved to live in the oil palm camp told me how she frequently heard a timang tiger spirit on their roof at night. She also told me about how an immigrant worker from eastern Indonesia working at the oil palm plantation fell acutely ill after meeting the timang on the road and later died on his way to the coast to seek medical help.

\section{REFERENCES}

Allerton, C. 2009. Introduction: Spiritual landscapes of Southeast Asia. Anthropological Forum 19, 235-51. Amster, M. 2009. Portable potency: Christianity, mobility and spiritual landscapes among the Kelabit. Anthropological Forum 19, 307-22.

2016. Animism and anxiety: religious conversion among the Kelabit of Sarawak. In Animism in Southeast Asia (eds) K. Århem \& G. Sprenger, 205-18. London: Routledge.

Århem, K. 2016. Southeast Asian animism in context. In Animism in Southeast Asia (eds) K. Århem \& G. Sprenger, 3-30. London: Routledge.

BeATTy, A. 2019. Speak no evil: inversion and evasion in Indonesia. In Engaging evil: a moral anthropology (eds) W. Olsen \& T. Csordas, 71-94. New York: Berghahn Books.

BIRD-DAVID, N. 1999. 'Animism' revisited: personhood, environment, and relational epistemology. Current Anthropology 40, S67-91.

2006. Animistic epistemology: why do some hunter-gatherers not depict animals? Ethnos 71, 33-50.

BLOCH, M. 2005. Ritual and deference. In Ritual and memory (eds) H. Whitehouse \& J. Laidlaw, 65-88. Walnut Creek, Calif.: AltaMira Press.

Bovensiepen, J. 2009. Spiritual landscapes of life and death in the central highlands of East Timor. Anthropological Forum 19, 323-38.

BubANDT, N. 2008. Ghosts with trauma: global imageries and the politics of post-conflict memory. In Conflict, violence, and displacement in Indonesia (ed.) E. Hedman, 275-301. Ithaca, N.Y.: Cornell Southeast Asia Program Publications.

2012. A psychology of ghosts: the regime of the self and the reinvention of spirits in Indonesia and beyond. Anthropological Forum 22, 1-23.

2014. The empty seashell: witchcraft and doubt on an Indonesian island. Ithaca, N.Y.: Cornell University Press.

2018. Anthropocene uncanny: nonsecular approaches to environmental change. In A non-secular Anthropocene: spirits, specters, and other nonhumans in a time of environmental change (ed.) N. Bubandt. AURA Working Papers 3, 2-16.

Buyandelger, M. 2013. Tragic spirits: shamanism, memory, and gender in contemporary Mongolia. Chicago: University Press.

CHAO, S. 2018. In the shadow of the palm: dispersed ontologies among Marind, West Papua. Cultural Anthropology 33, 621-49.

Cohen, J. 1996. Monster culture (seven theses). In Monster theory: reading culture (ed.) J. Cohen, 3-25. Minneapolis: University of Minnesota Press.

de la Cadena, M. 2010. Indigenous cosmopolitics in the Andes: conceptual reflections beyond 'politics'. Cultural Anthropology 25, 334-70. 
Descola, P. 2006. Beyond nature and culture: Radcliffe-Brown Lecture in Social Anthropology. Proceedings from the British Academy 139, 137-55.

Gan, E., A. Tsing, H. Swanson \& N. Bubandt 2017. Introduction: Haunted landscapes of the Anthropocene. In Arts of living on a damaged planet (eds) A. Tsing, H. Swanson, E. Gan \& N. Bubandt, G1-16. Minneapolis: University of Minnesota Press.

Haraway, D. 2015. Anthropocene, Capitalocene, Plantationocene, Chthulucene: making kin. Environmental Humanities 6, 159-65.

2017. Symbiogenesis, sympoiesis, and art science activisms for staying with the trouble. In Arts ofliving on a damaged planet (eds) A. Tsing, H. Swanson, E. Gan \& N. Bubandt, M25-50. Minneapolis: University of Minnesota Press.

Herrmans, I. 2015. Ritual retellings: Luangan healing performances through practice. New York: Berghahn Books.

2017. Values in practice: change and continuity in Luangan ritual performance. In Continuity under change in Dayak societies (eds) C. Arenz, M. Haug, S. Seitz \& O. Venz, 191-212. Wiesbaden: Springer.

Hopes, M. 1997. Ilmu: magic and divination amongst the Benuaq and Tunjung Dayak. Jakarta: Puspa Swara and Rio Tinto Foundation.

Howell, S. 2012. Knowledge, morality, and causality in a 'luckless' society: the case of the Chewong in the Malaysian rain forest. Social Analysis 56, 133-47.

InGOLD, T. 1999. Comment on Bird-David, N. 'Animism' revisited: personhood, environment, and relational epistemology. Current Anthropology 40, S81-2.

2000. The perception of the environment: essays on livelihood, dwelling and skill. London: Routledge.

Johnson, A. 2013. Progress and its ruins: ghosts, migrants, and the uncanny in Thailand. Cultural Anthropology 28, 299-319.

КонN, E. 2013. How forests think: toward an anthropology beyond the human. Berkeley: University of California Press.

LI, T.M. 2014. Land's end: capitalist relations on an indigenous frontier. Durham, N.C.: Duke University Press.

McEwan, C. 2008. A very modern ghost: postcolonialism and the politics of enchantment. Environment and Planning D: Society and Space 26, 29-46.

Nieuwenhuis, A.W. 1904-7. Quer durch Borneo: Ergebnisse seiner Reisen in der Jahren 1894, 1896-97 und 1898-1900. Leiden: Brill.

Remme, J. 2016. Actualizing spirits: Ifugao animism as onto-praxis. In Animism in Southeast Asia (eds) K. Århem \& G. Sprenger, 138-56. London: Routledge.

Roвbins, J. 2006. On giving ground: globalization, religion, and territorial detachment in a Papua New Guinea society. In Territoriality and conflict in an era of globalization (eds) M. Kahler \& B. Walter, 62-84. New York: Cambridge University Press.

RousseAu, J. 1998. Kayan religion: ritual life and religious reform in Central Borneo. Leiden: KITLV Press.

SCHILleR, A. 1997. Small sacrifices: religious change and cultural identity among the Ngaju of Indonesia. New York: Oxford University Press.

Siegel, J. 2006. Naming the witch. Stanford: University Press.

Sillander, K. 2011. Kinship and the dialectics of autonomy and solidarity among the Bentian of Borneo. In Anarchic solidarity: autonomy, equality, and fellowship in Southeast Asia (eds) T. Gibson \& K. Sillander, 141-69. New Haven: Yale Southeast Asia Studies.

2016. Relatedness and alterity in Bentian human-spirit relations. In Animism in Southeast Asia (eds) K. Århem \& G. Sprenger, 157-80. London: Routledge.

SPREnger, G. 2010. Sharing dreams: involvement in the other's cosmology. In Mutuality and empathy: self and other in the ethnographic encounter (eds) A.S. Grønseth \& D. Davis, 49-68. Wantage, Oxon: Sean Kingston. 2016. Graded personhood: human and non-human actors in the Southeast Asian uplands. In Animism in Southeast Asia (eds) K. Århem \& G. Sprenger, 73-90. London: Routledge.

Tsing, A. 1993. In the realm of the Diamond Queen. Princeton: University Press.

2005. Friction: an ethnography of global connection. Princeton: University Press.

2017. Threat to Holocene resurgence is a threat to livability. In The anthropology of sustainability: beyond development and progress (eds) M. Brightman \& J. Lewis, 51-65. New York: Palgrave Macmillan US.

Viveiros de Castro, E. 1998. Cosmological deixis and Amerindian perspectivism. Journal of the Royal Anthropological Institute (N.S.) 4, 469-88.

WAdley, R. \& C. Colfer 2004. Sacred forest, hunting, and conservation in West Kalimantan, Indonesia. Human Ecology 32, 313-38. 
Willerslev, R. 2007. Soul hunters: hunting, animism, and personhood among the Siberian Yukaghirs. Berkeley: University of California Press.

\& M. Pedersen 2010. Proportional holism: joking the cosmos into the right shape in North Asia. In Experiments in holism: theory and practice in contemporary anthropology (eds) T. Otto \& N. Bubandt, 300-19. Chichester: Wiley-Blackwell.

\section{Esprits délogés : paysages relationnels et bouleversements environnementaux dans le Kalimantan-Oriental (Indonésie)}

\section{Résumé}

Cet article examine la communication avec les esprits chez les Lawangan, une population de cultivateurs itinérants de la partie indonésienne de Bornéo. À travers des exemples de différentes formes d'interactions spirituelles, il interroge la relation entre le monde des esprits et l'environnement naturel, avec une attention particulière pour ce qu'il advient lorsque ce dernier subit des bouleversements spectaculaires. Puisant inspiration dans les travaux d'Eduardo Kohn sur l'ancrage sémiotique du monde des esprits dans la forêt tropicale, l'article montre comment les relations avec les non-humains reflètent des expériences passées et actuelles de vie et de socialité dans les domaines forestier et humain ; elles apposent également un paysage relationnel virtuel sur le paysage naturel. L'autrice avance que la communication avec les esprits constitue un moyen de réimaginer les vies humaines et de réduire le sentiment d'affaiblissement. Les rituels récurrents permettent aux Lawangan de maintenir virtuellement des relations avec des êtres invisibles de l'environnement local, y compris lorsque celui-ci est complètement transformé par la culture de l'huile de palme.

Isabell Herrmans is a research fellow at the Swedish School of Social Science, University of Helsinki. She is the author of Ritual retellings: Luangan healing performances through practice (Berghahn Books, 2015).

PO Box 16, FI-ooo14, University of Helsinki, Finland. isabell.herrmans@helsinki.fi 